\title{
The relationship between viral marketing and consumer purchase intention, the moderator role of brand image and age: Evidence from smartphone users in North Cyprus
}

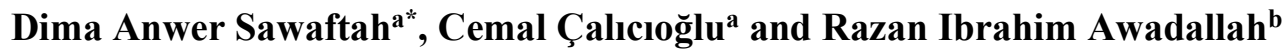

${ }^{a}$ Girne American University, Marketing Department, via Mersin 10, North Cyprus, Turkey

${ }^{b}$ Girne American University, Business Management Department, via Mersin 10, North Cyprus, Turkey

\section{H R O N I C L E}

\section{Article history:}

Received: October 25, 2019

Received in revised format: November 202019

Accepted: November 22, 2019

Available online:

November 22, 2019

Keywords:

Viral Marketing

Customer Purchase Intention

SmartPhones

Viral advertising

E-WOM

\section{A B S T R A C T}

This research aims to examine the effects of two viral marketing attributes; namely viral advertising and E-WOM on customer purchase intention. In particular, the authors contemplate the prima facie nature of the relationship by examining brand image and age as contingent boundary conditions (moderator role). The population of the study consists of graduate students in a private Cypriot university. A sample size of 177 participants is recruited using a convenience sampling technique. Multiple linear regression and analysis of variance are the statistical analyses employed to test the developed hypotheses. The findings reveal that viral marketing influenced on customer purchase intention magnified under the moderating role of brand image but age did not affect the relationship. Interestingly, viral advertising had a greater effect on customer purchase intention than E-WOM. Finally, discussions of this research finding in light of academic knowledge are put forward before suggesting future research directions.

\section{Introduction}

In the era of advancing technology and information change, communication and connectivity through the internet web have substantially risen (Hajli, 2014). The evolution of the web, as one of the technologic advancements, created a radical shift in the way firms interact with their consumes (Pinheiro et al., 2014). When forming a blueprint for viral marketing, a bundle of factors must be taken into consideration, such as platforms, media type, ads content, and targeted customers (Fill \& Turnbull, 2016). Viral marketing has generated a great revolution in the marketing world as a new technique, and most of it depends on marketing specialists and their face to face practice with customers; this method let the marketers select a few people through social media websites, blogs or general websites to plant their idea or product in a viral natural message and then leave it spread among the customers without any effort to reach an endless number of recipients who are working on the dissemination continuously. The philosophy of simple viral marketing based on e-mail has spread all over the world, and the word of mouth (WOM) has been used in dealing, promoting and selling, but face-to-face until the Internet has emerged and has made a significant shift in the world of marketing (Hmaed, 2014). Meaningful evaluations of any product or service are best done by seeking customers' feedback (Ugonna et al., 2017). This helps the problem floats on the surface to realize the effect of viral marketing, viral advertising, and electronic word of mouth on purchase intention. This relationship has been investigated from the professional marketer's perspectives (Alsamydai, 2016; Fritz \& Shaw, 2017; Saleem et al., 2017). The researcher is going to assert this issue by analyzing the customers' point of view, i.e. graduate students' perspective at GAU.

\footnotetext{
* Corresponding author.

E-mail address: deemamubaslat@gmail.com (D. Anwer Sawaftah) 
After reviewing the available recent studies we found a lack of studies that cover the exact relationship of this one, the study of (Rakib, 2019) which derived in Denmark to study the culture of Danish customers concentrated on "viral marketing message and customer purchase intention" as a primary variables, but did not use any secondary variable (moderate or mediator). Motwani and Haryani, (2018) derived their study by considering "viral marketing and consumer purchase intention" as primary variables, but did not use any secondary variable. Trivedi (2017) studied "viral marketing message and consumer behavioral intention" through the mediating effect of the brand in general. The study of Fritz et al. (2017)studied "viral marketing message and customer purchase intention" without any secondary variables. Regarding to the study of Trivedi (2017) sought to study the same relationship at the field of electronics taking into consideration the age of the customers; Hence, the researchers derived this research by combining the (viral advertising and E-WOM) as an attributes for the independent variable (viral marketing), where the dependent variable is (customer purchase intention), while brand image and age the moderators in Smartphones industry in North Cyprus.

The purpose of this research to test the efficiency of viral marketing that is conceptualized by viral advertising, and E-WOM on customer's purchase intention of smartphones, and which one of these dimensions have the best effect (Fritz et al., 2017; Kudeshia \& Kumar, 2017; Wang et al., 2018). In particular, we study the effect of brand image on customers' purchase intention on smartphones (Taivanjargal et al., 2018), while considering the effect of age on customers' purchase intention (Trivedi, 2017). The results of this study will deliver knowledge of the viral marketing effect on the purchase intention of customers of smartphones in Northern Cyprus.

\section{Literature Review}

\subsection{Viral Marketing}

Regarding the rapid growth of the marketing science continuously and especially over the internet, the marketing specialists are going to innovate what is new and study its impact on the consumer and how it affects their purchasing behavior, such as viral marketing (Trivedi, 2017). Mohr (2017) defined viral marketing as "a marketing technique that uses the Internet, social networking, and technologies to encourage people to engage in word of mouth, creating the potential for exponential growth in the message's exposure and influence". Viral marketing is a huge domain, as it carries too many of the communication forms, such as social media, e-mail, forums, blogs, websites and other communication means (Sin Wei \& Tunku Abdul Rahman, 2014). According to Kumar et al. (2015) one of the most important benefits of viral marketing is that it is cheaper to transmit the advertising among consumers, in addition to its high speed if it is compared to traditional marketing, where the users of the social media pay more attention to the message content. Berger and Menon (2014) stated that the viral marketing message depends on some issues such as, sociality of the message receiver or how he feels when talking about specific product with others, emotion and the last one the practical value.

\subsubsection{Viral Advertising}

One of the most common aspects of viral marketing is viral advertising (Dafonte-Gómez, 2014) According to Felbermayr and Nanopoulos, (2016) viral advertising is basically based on delivering the message with others especially friends, where the success of such issue depends on customers, because of that the customers will distribute the ads on their social networking sites profiles; they will be concentrating on the ads. Text body and will share it for the purpose of fun and pleasure (Pressgrove et al., 2017). Another important issue relating to viral marketing that it is not a necessity to invest large amounts of money for broadcasting, printing or distribution; this is an unavoidable gain because of its design, also it is more effective than traditional ways of advertising; the new generation that uses social networking sites does not believe in traditional ways, as the highly influential advertisements are more popular for this generation of subsidized and corporate-designed advertising (Arnold, 2018).

\subsubsection{Electronic Word of Mouth (E-WOM)}

The concept of electronic word of mouth (E-WOM) has appeared and varied through the appearance of social networking sites; where the individuals are able to record the ideas exchange and the related concepts to the brands of products or services with their friends through the Internet (Erkan, 2014). The word of mouth has become electronic in the social networking environment and has become one of the biggest benefits for social networking sites users, because of its popularity many consumers can freely express their opinions about companies, brands, products, and services. Faithful customers of any organization will play a mediator role with their E-WOM between the organization and organizations' product and the prospected customers in a way of making them real customers (Owino et al., 2014). E-WOM is a truthful supply of evidence that decreases threat and rises the assurance of customers' decision-making process (Berger \& Menon, 2014). On the other hand, the E-WOM will be a good predictor for the customer through the shared information when he evaluates the alternatives before doing the actual purchase, it might affect the purchase intention through its quality, quantity, and credibility.

\subsection{Customer Purchasing Intention}

The intention is a predictor of the theory of reasoned action (TRA) which in turn implementes a behavior regarding the personal attitude and his normative belief (Coleman et al., 2011). In the area of social psychology history, TRA produced significant research and revealed that the purpose of it is to clarify the hidden personal behavior (Kelkar et al., 2018) TRA model consisted of 4 hidden variables: "attitude, subjective norms, intention, and behavior". Consumer behavior is the actions 
of the consumer when exposed to stimuli either internal or external effects, in order to satisfy his desires or needs, which is a set of procedures, that start with the stage of feeling the need; search for information; evaluation of the alternatives, and end up with the stage of the actual purchasing and the feedback (Prasad \& Jha, 2014). There are many factors that are playing a vital role and affecting the customer purchase intention of a smartphone (Walia et al., 2015). For instance, there are some studies (e.g. Rakib, 2019; Taivanjargal et al., 2018; Tran, 2018; Uddin et al., 2015) which state that "Brand image, Product features, Social influence, price, design, brand name, perceived quality, durability, easy handling, ease of use, promotion of brands, phone size, appearance" will affect the customer purchase intention in smartphones field. Since the targeted customer is the main element of the market, and customer is looking for quality of the product and the services, so if companies want to increase the sales volume they should make the consumers feel the added-value of their products and services, which in its turn will increase their satisfaction (Chen et al., 2016).

\subsection{Brand Image}

The majority of the scholars approved the significance of emphasizing brand image; brand image is the main driver of brand equity, related to the customer overall awareness about the brand, and it has impact on consumer behavior (Hong \& Zhang, 2017). For instance, Aaker (1991) said that the image in several styles design the value, assisting consumers to handle information, distinguish the brand, spawning causes to purchase, offering progressive feelings, and offering a foundation for extensions. Manorek (2016) said that the image of the brand is the main part of any organization and the customer relationship, which means it has a greater value than name and logo. Brand image plays an important role in consumer behavior towards a product, so the organization in such competitive circumstances should take care of its product's brand image to catch new consumers and keep the actual consumers (Dunuwille \& Pathmini, 2016). Many studies assure that images of brands will increase confidence in customers' intentions of purchasing products (Harsono et al., 2018; Surjaatmadja \& Purnawan, 2018).

\section{Hypotheses Generation}

Three main hypotheses are derived according to the research questions which are about the independent variable and its dimensions (Viral marketing: viral advertising and E-WOM); the second and third ones are about the moderator variables (brand image and age).

\subsection{Viral Marketing and Customer Purchasing Intention}

There is an effect of viral marketing on customers' purchase intention that comes in parallel with earlier research (Rakib, 2019) which revealed that there is an effect of a viral marketing message on customer purchase intention. Similar to the study of Motwani and Haryani (2018) we expressed that there is an impact of viral marketing and consumer purchase intention. Fritz et al. (2017) performed a study in Johannesburg about the retail shops and indicated that there is an impact of viral marketing and customer purchase intention. Shashikala and Mahapatro (2015) performed a study about the WhatsApp and its turn in viral marketing in Bangalore and stated that there is an influence of viral marketing message on purchase intention. As a result of this review, the below hypothesis is derived regarding the current research.

$\mathbf{H}_{1}$ : Viral marketing has a positive effect on customer purchase intention.

\subsubsection{Viral Advertising and Customer Purchase Intention}

There is an effect of viral advertising on customers' purchase intention that comes in a parallel with earlier research (Wang \& Nguyen, 2018) who conducted a study that shows viral video has an influence on customer intention. Yaqoob (2018) proved that the mobile version of Facebook advertising has an effect on customer purchase intention. Alnsour (2018) stated in his study of the Jordanian airline industry that the customer purchase intention was affected by social media advertising. Alsamydai et al. (2016) study was conducted in Jordan and expressed that viral advertising (Facebook advertising) has an effect on customer attitude and then on customer purchasing intention. Thus, the below hypothesis is derived.

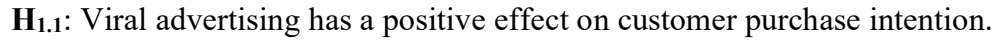

\subsubsection{E-WOM and Customer Purchasing Intention}

There is an effect of E-WOM on customers' purchase intention, Hennig et al. (2004) indicated that E-WOM is a useful drive for customers and firms in outlining their feelings about the purchased products either goods or services, the expressed feeling might be either positive or negative; Prospective customers are able to explore the product feedback and info over different online platforms such as social networking sites, applications and websites (Migin \& Falahat, 2016) that comes in a parallel with earlier researcher (Yusuf et al., 2018) who argue that S-commerce is a mixture of customers' commercial and social actions. Besides the study of Saleem et al. (2017) about branded fashion sector stated that there is an influence of E-WOM on customer intention; The study of Kudeshia and Kumar (2017) which conducted in the field of electronics stated that positive E-WOM through the SNS' has an effect on customer purchase intention. Hadi and Nejad (2017) conducted a survey in Iran about Mellat bank that came up with the result of the positive impact of E-WOM on customer purchase intention in the banking sector. In North Cyprus behavior intention was examined with E-WOM on Facebook hotel page for five stars' hotels (Ibrahim \& Aljarah, 2018), so the below hypothesis is derived. 
H1.2: E-WOM has a positive effect on customer purchase intention.

\subsubsection{Brand Image as Moderator}

The customers are expected to buy the familiar branded products which have a certain brand image, because it will reduce the perceived risk for them (AKAAH, 1988) or rising the value (Slater, 1998; Romaniuk \& Sharp, 2012). The brand image does not happen in the attributes, innovation or the veritable item itself, but instead, it is something brought out by commercials, advancements or clients. The brand picture is frequently utilized as an extraneous sign when customers are assessing an item before buying (Richardson et al., 1994; Zeithaml, 1988). Rahi (2016) stated in her study conducted in the banking sector in Pakistan that the brand image moderates the relationship between customer perceived value and customer perception on customer loyalty. Lin et al. (2015) conducted a study in Taiwan about restaurants between restaurant discount coupon depths on re-consumption willingness under the presence of brand image as a moderator, which result in that brand image moderated the relationship between the two mentioned variables. The study of Lin and Cheng (2011) presented the moderating role of "product involvement and brand image" between E-WOM and purchase intention.

From the above-mentioned studies, there is an assurance that when the brand image goes through any relationship will end up with a positive effect on the original one, so as a result of that, the below hypothesis is derived to fit the current research.

$\mathbf{H}_{2}$ : There is a positive effect of viral marketing on customer purchase intention and will be stronger under the presence of brand image.

\subsubsection{Age as Moderator}

There is an effect of age on moderating the relationship between viral marketing and customers' purchase intention which comes in parallel with the studies of Hardy et al. (2018) who stated that age moderates the relationship of "social media use and mental well-being"; Othuon and Mbagaya (2015) presented the positive role of age in moderating the relationship "Career Readiness and Career Indecision"; Sv and Sequeira (2014) stated that age affected positively the adoption of M-Banking in India; (Zia et al., 2010) which derived in Pakistan that age played a moderating on the relationship of job rewards and the satisfaction of the employee. So, as a result of the above-mentioned studies, the below hypothesis is derived.

$\mathbf{H}_{3}$ : There is a positive effect of viral marketing on customers' purchase intention and will be stronger under the presence of age.

\section{Conceptual Framework}

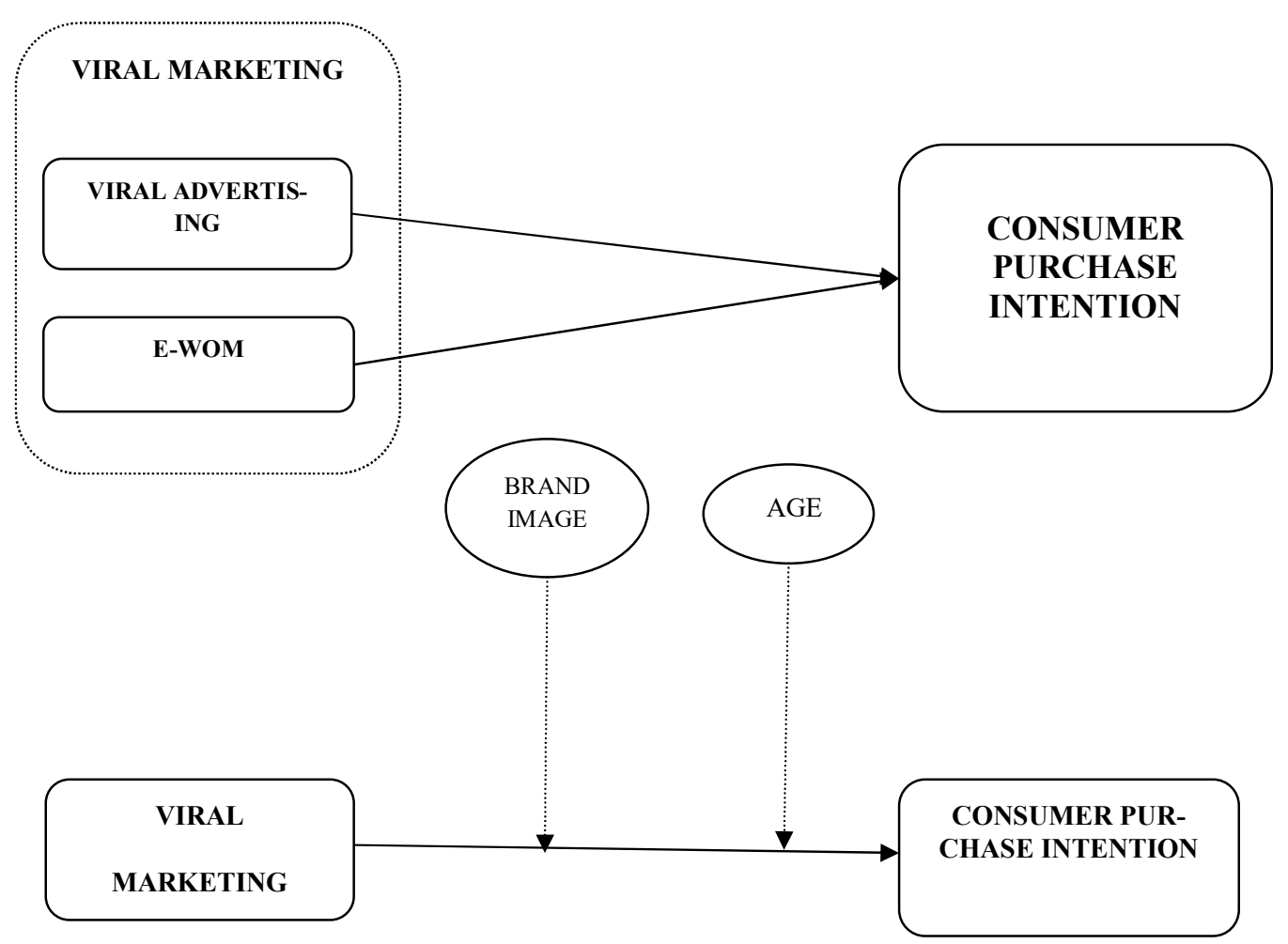

Fig. 1. the conceptual model of the research

Fig. 1 shows the conceptual model of the research and two dimensions of viral marketing (viral advertising, and E-WOM) have an effect on customer purchase intention (Rakib, 2019; Wang \& Nguyen, 2018; Yusuf et al., 2018) too many issues 
having an influence on smartphones purchase intention such as "Product Feature, Price, Quality, Design, Social influence, and Brand" (Rakib, 2019; Tran, 2018) measuring the moderating role of two variable which are brand image and gender (Hardy et al., 2018; Rahi, 2016).

\section{Methodology}

\subsection{Research Approach and Type}

This research depends on the "research onion" which is portraying a sum of phases that consist of the research "philosophies, approaches, choices, techniques, and procedures" (See Fig. 1).

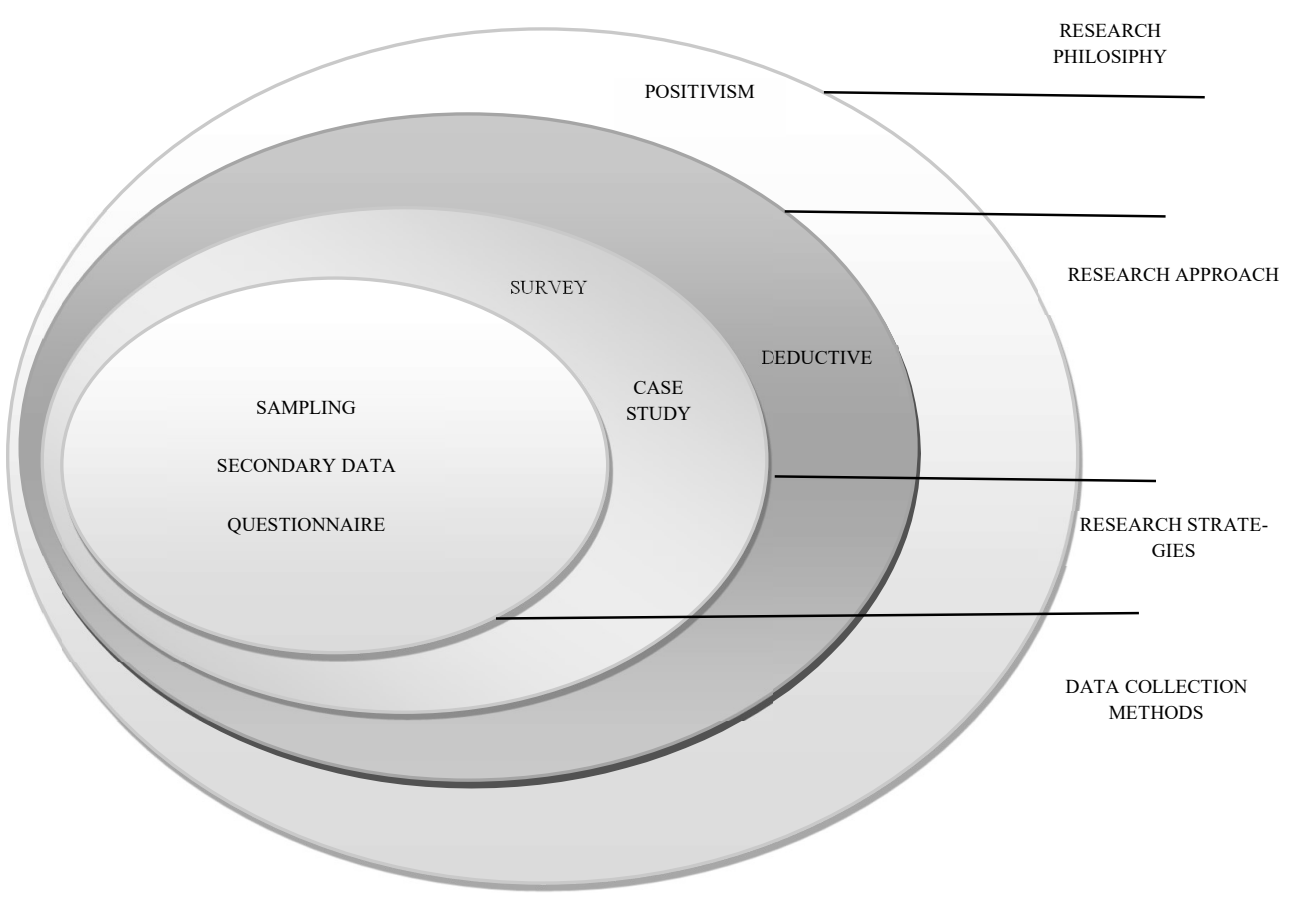

Fig. 2. Research Onion

Positivism philosophy was adopted to gain the needed data to explain and emphasize the research purposes, which consisted of the deductive approach, quantitate approach, by using the survey and case study strategies (Saunders et al., 2016). In addition to the deductive approach, analytical descriptive approach is used to deliver the needed data (which is numeric) to report the research problem, and answer its questions in an ideal way.

\subsection{Research Design and Strategies}

The targeted population is Girne American University graduate students because they own wide experience about the internet; social media top users and social media and e-commerce dynamic participants (Ismail, 2017) from where the sample was conducted in a way to generalize the results (Denise \& Faan, 2014). According to the research population which is 1800 students as mentioned in the university records, divided between the two degrees, the sample size estimated through the sample size calculator with a confidence interval of 10 and confidence level of $95 \%$, which counted 177 participants; none probability convenience sampling method was utilized to gain the needed data from the respondents. The researchers increased the sample size by 23 participants. The research instrument was a Five-Point Likert scale structured questionnaire to collect a large amount of data (Saunders et al., 2016) .

To confirm that the applicants (students) are energetic and using social networking sites and smartphones, a couple of screening questions were asked to the respondents:

- Do you use social networking sites daily?

- Do you provide any feedback about your purchased products on an e-commerce website or on the social networking site?

The survey was piloted by delivering 25 copies on a random sample of the graduate students to make sure that the survey suits the study and measure the required things that the study derived for. 


\subsection{Survey Reliability}

The survey was piloted by delivering a 25 copies on a random sample of the targeted population; the equation of Alpha Cronbach was used on the research determined sample to test the survey reliability and to ascertain the degree of internal consistency of its all parts; the stability coefficient assessment of Cronbach's Alpha is $81.7 \%$, which is greater than $70 \%$, and it is conventional, as shown in Table 1

Table 1

The result of Reliability Statistics (Cronbach Alpha)

\begin{tabular}{cc}
\hline Cronbach's Alpha & N of Items \\
\hline $81.7 \%$ & 30 \\
\hline
\end{tabular}

\section{The results of statistical analysis}

Using Emeagwali, (2015)Web-based Inferential Statistic Selector (WBISS), means and standard deviations were used to analyze respondents' responses to every single item on the survey. Next, simple and multiple linear regressions were determined to be appropriate for analyzing the sub and main hypotheses, respectively, while hierarchical multiple regression was used to identify independent variables that demonstrated greater effects on the dependent variables relative to others. Also, a Oneway ANOVA/ANCOVA is used to examine differences among the four age groups in the study sample. Finally, a Two-way ANOVA was used to examine the simple interaction effects among categorical independent variables. In order to process the data gained through the survey from (177) respondents, the Social Sciences Statistical Packages (SPPS) was operated. The results discussed (6) variables, one main and two dimensions as independent variables, one dependent variable, and two moderator variables, in addition to the respondent's demographic information.

\subsection{Demographic Variables Results}

Table 2

Percentage and frequency of Demographic

\begin{tabular}{|c|c|c|c|}
\hline Variable & Category & Frequency & $\%$ \\
\hline \multirow{5}{*}{ Age } & $<25$ & 67 & $\% 37.9$ \\
\hline & $26-31$ & 73 & $\% 41.2$ \\
\hline & $32-37$ & 26 & $\% 14.7$ \\
\hline & $>38$ & 11 & $\% 6.2$ \\
\hline & Total & 177 & $100 \%$ \\
\hline \multirow{3}{*}{ Gender } & Male & 133 & $\% 75.1$ \\
\hline & Female & 40 & $\% 24.9$ \\
\hline & Total & 177 & $100 \%$ \\
\hline \multirow{3}{*}{ Education Level } & Master Degree & 96 & $\% 54.2$ \\
\hline & Ph.D. Degree & 81 & $\% 45.8$ \\
\hline & Total & 177 & $100 \%$ \\
\hline \multirow{5}{*}{ Smartphone Brand } & IPhone & 99 & $\% 55.9$ \\
\hline & Samsung & 57 & $\% 32.2$ \\
\hline & Huawei & 9 & $\% 5.1$ \\
\hline & Other & 12 & $\% 6.8$ \\
\hline & Total & 177 & $100 \%$ \\
\hline \multirow{5}{*}{ Mobile Internet Usage } & Less than 14 hours & 54 & $\% 30.5$ \\
\hline & 14-20 hours & 57 & $\% 32.2$ \\
\hline & 20-30 hours & 38 & $\% 21.5$ \\
\hline & More than 30 hours & 28 & $\% 15.8$ \\
\hline & Total & 177 & $100 \%$ \\
\hline
\end{tabular}

As shown in Table 2, some demographic information was collected from respondents with regard to age, gender, educational level, Smartphone Brand and Mobile Internet Usage. The majority of the responses with the highest percentage were gained from males with $(75.1 \%)$ and females $(24.9 \%)$ of the sample; the majority of the respondents were in the age range of 26-31 years by $41.2 \%$ of the sample. This value is reasonable as the respondent of our study consists just postgraduate students, and depend on our study this two-age group considered the largest group of the sample since most of postgraduate were at least 23 years old. With regards to the respondents' educational background, the highest percentage was for the master degree $(54.2 \%)$; However, the highest percentage of the respondents was for iPhone users $(55.9 \%)$; Finally the majority percentage of Internet usage hours was for 14-20 hours category by $(32.2 \%)$ of the respondents and the lowest one was for those who use the Internet more than 30 hours by $(15.8 \%)$ the respondents.

\subsection{Testing the Hypotheses}

\subsubsection{The First Main Hypothesis}

$\mathrm{H}_{1}$ : Viral marketing has a positive effect on customer purchase intention. 
To examine this hypothesis validity "multiple linear regressions" was operated. As follow:

Table 3

Multiple Linear Regression for Examining the Effect of Viral Marketing on Customer Purchase Intention

\begin{tabular}{|c|c|c|c|c|c|c|c|}
\hline Independent Variable & $\mathrm{R}$ & $\mathrm{R}^{2}$ & $\mathrm{~F}$ & $\operatorname{Sig}(\mathrm{F})$ & $\mathrm{B}$ & $\mathrm{t}$ & $\operatorname{Sig}(\mathrm{T})$ \\
\hline $\begin{array}{c}\text { Viral Advertising } \\
\text { E-WOM }\end{array}$ & $.368^{\mathrm{a}}$ & .135 & 13.587 & $.000^{\mathrm{b}}$ & $\begin{array}{l}.308 \\
.167\end{array}$ & $\begin{array}{l}3.867 \\
2.155\end{array}$ & $\begin{array}{l}.000 \\
.033\end{array}$ \\
\hline
\end{tabular}

Table 3 presents the multiple linear regression for examining the effect of viral marketing on customer purchase intention. $\mathrm{R}^{2}$ $(\% 13.5)$ expresses the predictive power of the dependent variable by operating the independent variable, which is the same as the variance ratio of the dependent variable. In other words, the independent variable (viral marketing) interprets (13.5\%) of the variance of the dependent variable and the rest is interpreted by other independent variables; the correlation coefficient is (0.368), which means that the correlation between the two variants is on average. From the previous explanation, the hypothesis is accepted.

\subsubsection{Sub-hypotheses Testing}

\subsubsection{First Sub-hypothesis}

To examine the validity of the sub-hypotheses that pulled down from the first main hypothesis "simple linear regressions" was operated as follows:

$\mathrm{H}_{1.1}$ : Viral advertising has a positive effect on customer purchase intention.

Table 4

Simple Linear Regression for Examining the Effect of Viral Advertising on Customer Purchase Intention

\begin{tabular}{cccccc}
\hline Independent Variable & $\mathrm{R}$ & $\mathrm{R}^{2}$ & $\mathrm{~B}$ & $\mathrm{t}$ & $\mathrm{Sig}(\mathrm{T})$ \\
\hline Viral Advertising & $.335^{\mathrm{a}}$ & .112 & .360 & 4.698 & .000 \\
\hline
\end{tabular}

Noted from the Table 4 that $\mathrm{R}^{2}(\% 11.2)$ expresses the predictive power of the dependent variable by operating the independent variable, which is the same as the variance ratio of the dependent variable. In other words, the independent variable (viral advertising) interprets (11.2\%) of the variance of the dependent variable and the rest is interpreted by other independent variables; From the previous explanation, the hypothesis is accepted.

\subsubsection{Second Sub-hypothesis}

$\mathrm{H}_{1.2}$ : There is a positive direct impact of E-WOM on customer purchase intention

Table 5

Simple Linear Regression for Examining the Effect of E-WOM on Customer Purchase Intention

\begin{tabular}{cccccc}
\hline Independent Variable & $\mathrm{R}$ & $\mathrm{R}^{2}$ & $\mathrm{~B}$ & $\mathrm{t}$ & $\mathrm{Sig}(\mathrm{T})$ \\
\hline E-WOM & .246 & .061 & .258 & 3.364 & .001 \\
\hline
\end{tabular}

Noted from the Table 5 the $\mathrm{R}^{2}$ (\% 6.1) expresses the predictive power of the dependent variable by operating the independent variable, which is the same as the variance ratio of the dependent variable. In other words, the independent variable (E-WOM) interprets $(6.1 \%)$ of the variance of the dependent variable and the rest is interpreted by other independent variables. From the previous explanation, the hypothesis is accepted.

\subsubsection{Second Main Hypothesis}

$\mathrm{H}_{2}$ : There is a positive effect of viral marketing on customer purchase intention and it becomes stronger under the presence of brand image.

In order to examine the hypothesis, we must first examine the homogeneity of the variables, for this purpose Levene's Test of Equality of Error Variances was utilized as follows:

\section{Table 6}

Levene's Test of Equality of Error Variances

\begin{tabular}{cccc}
\hline F & Df1 & Df2 & Sig. \\
\hline 1.502 & 131 & 45 & .059 \\
\hline
\end{tabular}

Noted from the Table 6 that the value of statistical significance is equal to $(0.059)$ which is greater than $(0.05)$ so there is homogeneity between the values of the variables. 
Table 7

Two-way ANOVA

\begin{tabular}{lccccc}
\hline Source & Type III Sum of Squares & Df & Mean Square & F & Sig. \\
\hline Corrected Model & $63.681^{\mathrm{a}}$ & 131 & .486 & 6.656 & .000 \\
Intercept & 926.982 & 1 & 926.982 & 12691.947 & .000 \\
viral_ew & 31.967 & 79 & .405 & 5.540 & .000 \\
BA & 4.354 & 17 & .256 & 3.507 & .000 \\
viral_ew * PI & 12.932 & 34 & .380 & 5.208 & .000 \\
Error & 3.287 & 45 & .073 & & \\
Total & 2230.320 & 177 & & & \\
Corrected Total & 66.967 & 176 & & & \\
\hline
\end{tabular}

a. $\quad$ R Squared $=.951$ (Adjusted R Squared $=.808)$

Noted from the Table 7 that the value of the statistical significance by using the moderator (brand image) is less than (0.05); so, there is a statistical significance of the moderator variable in a positive increase. To verify the strength of the correlation between the variables, multiple regression was utilized

Table 8

Model Summary

\begin{tabular}{rcccc}
\hline Model & R & R Square & Adjusted R Square & Std. Error of the Estimate \\
\hline 1 & $.418^{\mathrm{a}}$ & .174 & .160 & .56534 \\
\hline
\end{tabular}

Table 8 verified that independent variables explain $(17.4 \%)$ of the dependent variable variance. The correlation coefficient after the entry of the brand image is $(0.418)$ while it was $(0.368)$ before brand image usage. This means that the brand image increased the correlation positiveness between the variables and also the regression is significant because the value of the statistical significance is (zero) which is less than (5\%). To illustrate the type of relationship and which one of the variables has a greater effect on the dependent variable after the entry of the brand image, Table 9 presents the variables and beta values of it.

Table 9

Beta Values of the Variables

\begin{tabular}{|c|c|c|c|c|c|c|}
\hline & \multirow[t]{2}{*}{ Model } & \multicolumn{2}{|c|}{ Unstandardized Coefficients } & \multirow{2}{*}{$\begin{array}{c}\text { Standardized Coefficients } \\
\text { Beta }\end{array}$} & \multirow[t]{2}{*}{$\mathrm{t}$} & \multirow[t]{2}{*}{ Sig. } \\
\hline & & B & Std. Error & & & \\
\hline \multirow{4}{*}{1} & (Constant) & 1.393 & .356 & & 3.917 & .000 \\
\hline & EW & .108 & .079 & .103 & 1.369 & .173 \\
\hline & VA & .275 & .079 & .255 & 3.478 & .001 \\
\hline & PI & .229 & .080 & .211 & 2.868 & .005 \\
\hline
\end{tabular}

Note from the Table 9 that the highest beta value is for viral advertising, which remains the most effective variable on purchase intention. From the previous explanation, the hypothesis is accepted.

\subsubsection{Third Main Hypothesis}

$\mathrm{H}_{3}$ : There is a positive effect of viral marketing on customers' purchase intention, and it becomes stronger under the presence of age.

Multiple linear regression was operated to examine the positive effect of the age groups entry as a moderator variable, which is presented in Table 10 as follows,

Table 10

Model Summary

\begin{tabular}{ccccc}
\hline Model & $\mathrm{R}$ & R Square & Adjusted R Square & Std. Error of the Estimate \\
\hline 1 & $.368^{\mathrm{a}}$ & .135 & .120 & .57861 \\
\hline
\end{tabular}

Table 10 presents that the correlation coefficient has not changed. By using the one way- ANOVA test.

Table 11

ANOVA

\begin{tabular}{lccccc}
\hline Model & Sum of Squares & Df & Mean Square & F & Sig. \\
\hline Regression & 9.049 & 3 & 3.016 & 9.010 & $.000^{\mathrm{b}}$ \\
Residual & 57.918 & 173 & .335 & & \\
\hline Total & 66.967 & 176 & & & \\
\hline
\end{tabular}

a. Dependent Variable: PI

b. Predictors: (Constant), VA, Age, EW 
It is clear from the Table 11 that the value of the statistical significance is less than (0.05). Therefore, we reject the hypothesis and accept the null one, so there is no positive effect of age group entry on the independent variables. To illustrate the relationship type and which one has a greater effect, Table 12 presents the regression coefficients and beta values.

Table 12

Regression Coefficients

\begin{tabular}{|c|c|c|c|c|c|c|}
\hline \multirow{2}{*}{\multicolumn{2}{|c|}{ Model }} & \multicolumn{2}{|c|}{ Unstandardized Coefficients } & \multirow{2}{*}{$\frac{\text { Standardized Coefficients }}{\text { Beta }}$} & \multirow[t]{2}{*}{$\mathrm{T}$} & \multirow[t]{2}{*}{ Sig. } \\
\hline & & $\mathrm{B}$ & Std. Error & & & \\
\hline \multirow{4}{*}{1} & (Constant) & 1.914 & .322 & & 5.943 & .000 \\
\hline & Age & -.005 & .050 & -.007 & -.101 & .920 \\
\hline & EW & .167 & .078 & .160 & 2.149 & .033 \\
\hline & VA & .309 & .080 & .287 & 3.852 & .000 \\
\hline
\end{tabular}

The results indicate that viral advertising has the highest beta value, which presents the highest effect on the dependent variable. From the previous explanation, the hypothesis is rejected.

\subsubsection{Hierarchical - Multiple Linear Regression}

To examine which of the independent variables by entering the moderator variable has a greater effect on the dependent variable (purchase intention) the Hierarchical - Multiple Linear Regression is operated as follows:

Table 13

Correlations

\begin{tabular}{|c|c|c|c|c|c|}
\hline & & PI & VA & EW & BA \\
\hline \multirow{4}{*}{ Pearson Correlation } & PI & 1.000 & .335 & .246 & .302 \\
\hline & VA & .335 & 1.000 & .304 & .229 \\
\hline & EW & .246 & .304 & 1.000 & .313 \\
\hline & PI & .302 & .229 & .313 & 1.000 \\
\hline \multirow{4}{*}{ Sig. (1-tailed) } & PI & & .000 & .000 & .000 \\
\hline & VA & .000 & . & .000 & .001 \\
\hline & EW & .000 & .000 & . & .000 \\
\hline & PI & .000 & .001 & .000 & . \\
\hline \multirow{4}{*}{$\mathrm{N}$} & PI & 177 & 177 & 177 & 177 \\
\hline & VA & 177 & 177 & 177 & 177 \\
\hline & EW & 177 & 177 & 177 & 177 \\
\hline & PI & 177 & 177 & 177 & 177 \\
\hline
\end{tabular}

Table 13 shows the Pearson correlation coefficient between the independent variables and the moderating variable; this study implemented the Pearson correlation method in SPSS to regulate how closely the variables of attention co-vary with each other. The consistent directions contain a -1 (perfect negative correlation), 0 (no correlation) to +1 (perfect positive correlation) (Alshanty et al., 2019). According to Table 13, there is an average correlation between the dependent variable and the independent variables (Pearson correlation coefficient is between 0 and 0.5 ). it is clear that the statistical significance value is less than 0.05 , therefore and there is a statistical significance among the correlations.

Table 14

Model Summary

\begin{tabular}{ccccccccccc}
\hline Model & $\mathrm{R}$ & $\mathrm{R}^{2}$ & $\begin{array}{c}\text { Adjusted R } \\
\text { Square }\end{array}$ & & $\begin{array}{c}\text { Std. Error of the } \\
\text { Estimate }\end{array}$ & & \multicolumn{4}{c}{ Change Statistics } \\
\cline { 7 - 11 } & & & & & $\begin{array}{c}\text { R Square } \\
\text { Change }\end{array}$ & F Change & df1 & df2 & $\begin{array}{c}\text { Sig. F } \\
\text { Change }\end{array}$ \\
\hline 1 & $.335^{\mathrm{a}}$ & .112 & .107 & .58293 & .112 & 22.071 & 1 & 175 & .000 \\
2 & $.368^{\mathrm{b}}$ & .135 & .125 & .57696 & .023 & 4.642 & 1 & 174 & .033 & \\
3 & $.418^{\mathrm{c}}$ & .174 & .160 & .56534 & .039 & 8.225 & 1 & 173 & .005 \\
\hline
\end{tabular}

a. Predictors: (Constant), VA

b. Predictors: (Constant), VA, EW

c. Predictors: (Constant), VA, EW, BI

d. Dependent Variable: PI

Table 14 illustrates the correlation coefficient values with the entry of each variable on the models; the correlation coefficient Value of (VA) is (0.335) where the percentage of the variation interpretation is $(11.2 \%)$. The correlation coefficient Value of (VA, E-WOM) is (0.368) where the percentage of the variation interpretation is (13.5\%). Moreover, the correlation coefficient Value of (VA, E-WOM, BI) is $(0.418)$ where the percentage of the variation interpretation is $(17.4 \%)$. To illustrate the correlation statistical significance of the variables, Table 15 presents the ANOVA. 
Table 15

ANOVA

\begin{tabular}{|c|c|c|c|c|c|c|}
\hline & Model & Sum of Squares & Df & Mean Square & $\mathrm{F}$ & Sig. \\
\hline \multirow{3}{*}{1} & Regression & 7.500 & 1 & 7.500 & 22.071 & $.000^{\mathrm{b}}$ \\
\hline & Residual & 59.467 & 175 & .340 & & \\
\hline & Total & 66.967 & 176 & & & \\
\hline \multirow{3}{*}{2} & Regression & 9.045 & 2 & 4.523 & 13.587 & $.000^{\mathrm{c}}$ \\
\hline & Residual & 57.922 & 174 & .333 & & \\
\hline & Total & 66.967 & 176 & & & \\
\hline \multirow{3}{*}{3} & Regression & 11.674 & 3 & 3.891 & 12.175 & $.000^{\mathrm{d}}$ \\
\hline & Residual & 55.293 & 173 & .320 & & \\
\hline & Total & 66.967 & 176 & & & \\
\hline
\end{tabular}

a. Dependent Variable: PI

b. Predictors: (Constant), VA

c. Predictors: (Constant), VA, EW

d. Predictors: (Constant), VA, EW, BA

Table 15 shows that all statistical significance values are less than 0.05 , which means there are statistical differences between the independent variables, the moderating variable and the dependent variable in the three models. To illustrate the regression equation models, Table 16 is presented:

Table 16

Coefficients

\begin{tabular}{|c|c|c|c|c|c|c|}
\hline & \multirow[t]{2}{*}{ Model } & \multicolumn{2}{|c|}{ Unstandardized Coefficients } & \multirow{2}{*}{$\begin{array}{c}\text { Standardized Coefficients } \\
\text { Beta } \\
\end{array}$} & \multirow[t]{2}{*}{$\mathrm{T}$} & \multirow[t]{2}{*}{ Sig. } \\
\hline & & $\mathrm{B}$ & Std. Error & & & \\
\hline \multirow{2}{*}{1} & (Constant) & 2.294 & .260 & & 8.833 & .000 \\
\hline & VA & .360 & .077 & .335 & 4.698 & .000 \\
\hline \multirow{3}{*}{2} & (Constant) & 1.907 & .313 & & 6.086 & .000 \\
\hline & VA & .308 & .080 & .286 & 3.867 & .000 \\
\hline & EW & .167 & .078 & .159 & 2.155 & .033 \\
\hline \multirow{4}{*}{3} & (Constant) & 1.393 & .356 & & 3.917 & .000 \\
\hline & VA & .275 & .079 & .255 & 3.478 & .001 \\
\hline & EW & .108 & .079 & .103 & 1.369 & .173 \\
\hline & PI & .229 & .080 & .211 & 2.868 & .005 \\
\hline
\end{tabular}

Table 17 presents three models of regression equation by adding and removing variables on them, and to illustrate these models Table 17 is presented.

Table 17

Excluded Variables

\begin{tabular}{lllllcc}
\hline Model & & Beta In & T & Sig. & Partial Correlation & $\begin{array}{c}\text { Collinearity Statistics } \\
\text { Tolerance }\end{array}$ \\
\hline \multirow{2}{*}{1} & EW & $.159^{\mathrm{b}}$ & 2.155 & .033 & .161 & .908 \\
& BA & $.237^{\mathrm{b}}$ & 3.336 & .001 & .245 & .947 \\
\hline 2 & BA & $.211^{\mathrm{c}}$ & 2.868 & .005 & .213 & .882 \\
\hline
\end{tabular}

a. Dependent Variable: PI

b. Predictors in the Model: (Constant), VA

c. Predictors in the Model: (Constant), VA, EW

Table 17 presents the results by excluding E-WOM and brand image from the first model, while excluding the brand image in the second model. From the previous explanation, it is obvious that adding the moderator variable (Brand Image) to the original relationship strengthen the effect of viral marketing on the purchase intention; and viral advertising has a greater impact on the purchase intention than E-WOM either with/without the moderator.

\section{Discussion}

The findings of this research have verified two main hypotheses and two sub-hypotheses, where the third main hypothesis was rejected. The first main hypothesis verified the positive influence of viral marketing in general on consumer purchase intention, this result came in a line with the studies' results in the literature (e.g. Fritz et al., 2017; Motwani \& Haryani, 2018; Rakib, 2019; Shashikala \& Mahapatro, 2015), which were carried out in different countries and different sectors and arrived at the same results of this research. Regarding to the first attribute of the independent variable (Viral Marketing) in this study which is viral advertising related to the first sub-hypothesis, the result revealed a strong influence on consumer purchase 
intention, this result comes in parallel with other studies (e.g. Alnsour, 2018; Alsamydai, 2016; Sabri, 2019; S. Wang \& Nguyen, 2018; YAQOOB, 2018) where viral advertising got several images such as Facebook advertising, social media networks advertising, and viral advertising in general, in several countries and different sectors. According to the second attribute, E-WOM affected the consumer purchase intention, related to the second sub-hypothesis this result is similar with the derived results from other studies (e.g. Kazmi \& Mehmood, 2016; Kunja \& GVRK, 2018) which operated on the same field of smartphones via other variables, such as "value co-creation", "brand image and product type" and brand image respectively. This is similar to some studies (e.g. Hadi \& Nejad, 2017; Kala \& Chaubey, 2018; Kudeshia \& Kumar, 2017; Sa, Kanyan, \& Nazrin, 2016; Saleem, Anum; Ellahi, 2017; Yusuf et al., 2018) which emphasized the same result of the current research that there is an influence of E-WOM in different degrees on the purchase intention. From the previous explanation, and the hypothesis verification, both viral advertising and E-WOM have an influence on the purchase intention, but viral advertising gained a greater effect than E-WOM.

In terms of the effect of brand image to moderate the relationship between viral marketing and consumer purchase intention, the results have indicated that the relationship between the two mentioned variables is stronger than it is absent, such a delivered result was the same as other studies results but in different relations (e.g. Kala \& Chaubey, 2018; M. L. Lin, 2016) "EWOM and purchase intention"; (Rahi, 2016) "Customer perceived value and customer perception on customer loyalty"; (Chen et al., 2016), "Restaurant discount coupon depths on re-consumption willingness"; (Liao et al., 2007) "Public Relation and Customer loyalty".

By going back to the role of age group to moderate the relationship between viral marketing and customers' purchase intention there was not any change in the relationship, and this result did not meet the results of the studies in other sectors (MolinerVelázquez et al., 2015; Hardy et al., 2018; Othuon \& Mbagaya, 2015; Schmidt, Miles, \& Welsh, 2011; Sv \& Sequeira, 2014; Zia et al., 2010), but it came consistent with some other studies (Duodu \& Amankwah, n.d.; Mohd Isa \& Wong, 2015). This might be because most of the generations were more Internet-savvy and most of them had previous experiences in many webtransactions; thus, they had a vision and appropriate resistance against some forms of viral marketing, which drives them not to deal seriously with it.

Briefly, viral marketing portrayed a useful role in modifying consumer purchase intention, by using different tools or techniques such as viral advertising and E-WOM; this might refer to the technology wide diffusion in the entire world, the marketing field has been developing increasingly; the customer is the main element of the marketing process, where the customer was the primary target of the process, regarding to the presence of the social networking sites and the use of SNS by the all levels and ages of the people, it became an important promotional tool for different products and services.

In addition to the human nature which is influenced negatively or positively by the views of others, especially the trusted ones for them, like families, relatives, friends, or maybe they will be affected by some famous figures, and they like to imitate them; hence, the customers will keep tracking the predecessor's purchase views and experiences a particular product or service. Furthermore, the current research will add value to smartphone dealers and manufactures in specific, while other organizations, in general, might benefit from our results in drawing their marketing plans. These plans devise which tools will assist them more in marketing and selling their products and services, which is the main aim of any organization; and then to attract more customers and converting the potential one to actual customers. In addition to expanding the awareness of the causes that are manipulating the purchase intention.

\subsection{Conclusion}

Based on what has been discussed in the current research regarding to the viral marketing with its gained attributes (viral advertising and E-WOM) on consumer purchasing intent, under the presence of (brand image and age) as moderators, it shows that there is a significant impact of viral marketing on consumer buying intent of smartphone in Northern Cyprus. The effect of viral advertising was greater than E-WOM, either with/without the brand image. No impact of age groups on the main relationship was found. Despite these results, it is the organizations' responsibility to focus more on viral marketing through its various techniques, different sectors and fields because of its great impact on marketing and advertising of several products and services in many directions, it is cheaper than other marketing channels; also its diffusion speed, in which the organizations can obtain a bigger consumers market share by leaving a mark in the mind of the consumer about the product in particular and the company in general.

\subsection{Limitation, Recommendations, and future researches}

As any other research, this research faced a number of obstacles, where the most important one was the needed time to collect the required data from the targeted population, of obtaining the required data from the research community, which should have been collected in a longer period of time, from more than one city and more than one category of smartphones users in Northern Cyprus. In other words, the targeted sample should be bigger and from different life categories in a better way to disseminate the results. In addition to the respondent's unawareness of some terms related to the research subject, which made them failed to answer some of the paragraphs in a proper way. This is due to the fact that the marketing campaigns do not promote the idea to consumers in an appropriate manner; sometimes it will be due to the lack of creativity in the message or idea delivering methods, which ultimately leads to consumers' lack of interest in the required form. 
In the context of this subject, there are a number of recommendations which must be taken into account either in the practical or the academic field; the practical one will cover particularly the smartphones companies and the organizations in general too; the most important direction is the need to choose the appropriate marketing techniques for the advertised product and in an effective and creative manner. The consumer should be exposed to a similar set of content ads that deliver the same idea to the same product to the consumer; these ads will be advertised for a specific period of time, which will ultimately stimulate the buying decision of the promoted commodity by using the viral advertising campaign. In conducting viral campaigns, companies must provide all information about the product that consumers are looking for with a high degree of credibility and integrity in an efficient and attractive way to obtain a greater market share. Companies should also provide appropriate and permanent training for the company marketing department to encourage employees to create, innovate and constantly learn about every new thing e-marketing world.

As for the academic part, the researchers propose to study other viral marketing techniques such as buzz marketing. In addition, we recommend studying the effect of other factors on the main relationship of this research, such as the respondent's gender and perceived value in different sectors. Furthermore, potential mediators such as product familiarity or product category should be considered. Also, from statically side, future studies can emphasis to conduct a meta-analysis study particularly in the light of the fact that there are a number of quantitative studies that have accompanied over the area of viral marketing and consumer purchase intention. The future meta-analysis studies can explore the moderator effect e.g. economic development (compare developing and developed countries) based on the study of Aljarah et al. (2018). Thus, it is believed that such research endeavors would contribute to the current literature.

\section{References}

AKAAH, \& P., I. (1988). A conjoint investigation of the relative importance of risk relievers in direct marketing. Journal of Advertising Resources, 38-44.

Aljarah, A., Emeagwali, L., Ibrahim, B., \& Ababneh, B. (2018). Does corporate social responsibility really increase customer relationship quality? A meta-analytic review. Social Responsibility Journal.

Alnsour, M. (2018). Social Media Effect On Purchase Intention: Jordanian Airline Industry. Journal of Internet Banking and Commerce, 23(2).

Alsamydai, M. J. (2016). The trust of viral advertising messages and its impact on attitude and behaviour intentions of consumers. International Journal of Marketing Studies, 8(5), 136-145.

Alshanty, A. M., Emeagwali, O. L., \& Alrwashdeh, M. (2019). The effect of market-sensing capability on knowledge creation process and innovation Evidence from SMEs in Jordan. https://doi.org/10.5267/j.msl.2019.1.016

Arnold. (2018). Successful Methods of Viral Marketing. (May).

Aaker, D. A., \& Equity, M. B. (1991). Capitalizing on the Value of a Brand Name. New York, 28(1), 35-37.

Berger, J., \& Menon, G. (2014). When identity marketing backfires: Consumer agency in Iidentity Expression. Journal of Consumer Research, 41(August). https://doi.org/10.1086/676125

Chen, Y., Chen, T., \& Lin, C. (2016). The analyses of purchasing decisions and brand loyalty for smartphone consumers. Open Journal of Social Sciences, July, 108-116.

Coleman, L. J., Bahnan, N., Kelkar, M., \& Curry, N. (2011). Walking the walk: How the theory of reasoned action explains adult and student intentions to go green. Journal of Applied Business Research, 27(3), 107-116.

Dafonte-Gómez, A. (2014). The key elements of viral advertising. From motivation to emotion in the most shared videos. Comunicar, 22(43), 199-206. https://doi.org/10.3916/C43-2014-20

Denise, P., \& Faan, F. P. (2014). Essentials Of Nursing Research : Appraising Evidence For Nursing.

Dunuwille VM and Pathmini MGS. (2016). Brand image and customer satisfaction in mobile phone market: study based on customers in Kandy district. Journal of Business Studies, 3(June), 1-13.

Duodu, F. K., \& Amankwah, T. (n.d.). MASTER' S THESIS An Analysis and Assessment of Customer Satisfaction with Service Quality in Insurance Industry in Ghana.

Emeagwali, O. L. (2015). Web-based Inferential Statistic Selector.

Erkan, I. (2014). "Vine": Do you miss it? Electronic word of mouth on the social networking site, Vine. International Journal of Business and Information, 9(4), 461-473.

Moliner-Velázquez, B., Ruiz-Molina, M. E., \& Fayos-Gardó, T. (2015). Satisfaction with service recovery: moderating effect of age in word-of-mouth. Journal of Consumer Marketing, 32(6), 470-484.

Felbermayr, A., \& Nanopoulos, A. (2016). ScienceDirect The Role of Emotions for the Perceived Usefulness in Online Customer Reviews. Journal of Interactive Marketing, 36, 60-76.

Fill, C., \& Turnbull, S. (2016). Marketing Communications. Pearson Higher Ed.

Fredericks, J. O. \& Slater, J. M. (1998). What Does Your Customer Really Want Quality. Course Hero.

Fritz, T., Corresponding, R., \& Shaw, G. (2017). Viral marketing strategies and customer buying behavioural intentions at retail store in Johannesburg. Business Management and Strategy, 8(1). https://doi.org/10.5296/bms.v8i1.10676

Hadi, S., \& Nejad, M. (2017). Brand Personality toward Customer Purchase Intention : The Intermediate Role of Electronic Word-of-Mouth and Brand. (January 2016). https://doi.org/10.21315/aamj2016.21.2.1

Hajli, M. N. (2014). A study of the impact of social media on consumers. International Journal of Market Research, 56(3), $387-404$

Hardy, B. W., \& Castonguay, J. (2018). The moderating role of age in the relationship between social media use and mental well-being: An analysis of the 2016 General Social Survey. Computers in Human Behavior, 85, 282-290. 
Harsono, S., Perdana, S., Riyadi, D. B., \& Normasita. (2018). The Influence of Brand Image, Brand Trust, Perceived Quality and Perceived Value on Consumer Purchase Intention at Different Categories of Product. Advanced Science Letters, 24(5), 3198-3207.

Hennig-Thurau, T., Gwinner, K. P., Walsh, G., \& Gremler, D. D. (2004). Electronic word-of-mouth via consumer-opinion platforms: What motivates consumers to articulate themselves on the Internet? Journal of Interactive Marketing, 18(1), $38-52$.

Hmaed, A. Z. (2014). Viral marketing and its inception, concept, Stages of his campaign, measure. Journal of Economic and Administrative Sciences, University of Baghdad, 20(76), 150.

Hong, D., \& Zhang, L. (2017). Does Transactive Memory Systems Promote Knowledge Integration Directly? Procedia Computer Science, 112, 896-905. https://doi.org/10.1016/j.procs.2017.08.107

Ibrahim, B., \& Aljarah, A. (2018). Data in Brief Dataset of relationships among social media marketing activities , brand loyalty, revisit intention . Evidence from the hospitality industry in Northern Cyprus. Data in Brief, 21, $1823-1828$. https://doi.org/10.1016/j.dib.2018.11.024

Ismail, A. R. (2017). The influence of perceived social media marketing activities on brand loyalty The mediation effect of brand. 29(1), 129-144. https://doi.org/10.1108/APJML-10-2015-0154

Kala, D., \& Chaubey, D. S. (2018). The effect of eWOM communication on brand image and purchase intention towards lifestyle products in India. Int. J. Services, Economics and Management, 9(2), 143-157.

Kazmi, A., \& Mehmood, Q. S. (2016). The effect of electronic word of mouth communication and brand image on purchase intention: A case of consumer electronics in Haripur, Pakistan. Management Science Letters, 6, 499-508.

Kelkar, M., Coleman, L. J., Bahnan, N., \& Manago, S. (2014). Green consumption or green confusion. Journal of Strategic Innovation and Sustainability, 9(1/2), 41.

Kudeshia, C., \& Kumar, A. (2017). Social eWOM: does it affect the brand attitude and purchase intention of brands?. Management Research Review, 40(3), 310-330.

Kumar, A., Bezawada, R., Rishika, R., Janakiraman, R., \& Kannan, P. K. (2016). From social to sale: The effects of firmgenerated content in social media on customer behavior. Journal of Marketing, 80(1), 7-25.

Kunja, S. R., \& GVRK, A. (2018). Examining the effect of eWOM on the customer purchase intention through value cocreation (VCC) in social networking sites (SNSs): A study of select Facebook fan pages of smartphone brands in India. Management Research Review. https://doi.org/10.1108/MRR-04-2017-0128

Liao, S. H., Fei, W. C., \& Chen, C. C. (2007). Knowledge sharing, absorptive capacity, and innovation capability: an empirical study of Taiwan's knowledge-intensive industries. Journal of Information Science, 33(3), 340-359.

Lin, C., Wu, Y. S., \& Chen, J. C. V. (2013, May). Electronic word-of-mouth: The moderating roles of product involvement and brand image. In Proceedings of 2013 international conference on technology innovation and industrial management (pp. 29-47).

Lin, M. L., Yang, J. T., \& Wan, C. S. (2015). Effect of restaurant discount coupon depth on re-consumption willingness: A moderating role of brand image. Tourism and Hospitality Research, 15(3), 193-205.

Manorek, S. L. (2016). The Influence of Brand Image, Advertising, Perceived Price Toward Consumer Purchase Intention (Case Study: Samsung Smartphone). Jurnal Berkala Ilmiah Efisiensi, 16(1), 661-670.

Migin, M. W., \& Falahat, M. (2016). Effect of social media usage on university students in an emerging country. Turkish Online Journal of Educational Technology, 2016(NovemberSpeciallssue), 803-808.

Mohd Isa, S., \& Wong, K. Y. (2015). Age differences in behavioral intention to use internet marketing: A comparative study between malaysian and taiwanese. International Journal of Business and Society, 16(3), 386-396.

Mohr, I. (2017). Managing buzz marketing in the digital age. Journal of Marketing Development and Competitiveness, 11(2).

Motwani, B., \& Haryani, S. (2018). Investigating the relation between factors effecting viral marketing and consumers' buying intention. European Journal of Applied Business and Management, 4(2). 58-73.

Othuon, L., \& Mbagaya, C. (2015). Moderating Role Of Age On The Relationship Between Career Readiness And Career Indecision. In British Journal of Psychology Research (Vol. 3).

Owino, E. O., Kibera, F., Munyoki, J., \& Wainaina, G. (2014). Service quality in Kenyan universities dimensionality and contextual analysis. European Journal of Business and Management, 6(11), 180-195.

Pinheiro, M. T., Borges Tiago, M., Manuel, J., \& Veríssimo, C. (2014). Digital marketing and social media: Why bother? Business Horizons, 57, 703-708. https://doi.org/10.1016/j.bushor.2014.07.002

Prasad, R. K., \& Jha, M. K. (2014). Consumer buying decisions models: A descriptive study. International Journal of Innovation and Applied Studies, 6(3), 2028-9324.

Pressgrove, G., Mckeever, B. W., \& Jang, S. M. (2017). What is Contagious? Exploring why content goes viral on Twitter : A case study of the ALS Ice Bucket Challenge What is Contagious? Exploring why content goes viral on Twitter : A case study of the ALS Ice Bucket Challenge. (August). https://doi.org/10.1002/nvsm.1586

Rahi, S. (2016). Impact of customer perceived value and customer's perception of public relation on customer loyalty with moderating role of brand image. Journal of Internet Banking and Commerce, 21(2).

Rakib, M. R. H. K. (2019). Factors influencing purchase intention of cellular phones among the university students in Bangladesh. 11, 92-101. DOI: 10.7176/EJBM/11-2-10

Richardson, P. S., Dick, A. S., \& Jain, A. K. (1994). Extrinsic and intrinsic cue effects on perceptions of store brand quality. Journal of Marketing, 58(4), 28-36. https://doi.org/10.1177/002224299405800403

Romaniuk, J., \& Sharp, B. (2012). Brand salience and customer defection in subscription markets and Byron Sharp. Journal 
of Marketing Research, (October 2014), 37-41. https://doi.org/10.1080/0267257X.2003.9728200

Sa'ait, N., Kanyan, A., \& Nazrin, M. F. (2016). The effect of e-WOM on customer purchase intention. International Academic Research Journal of Social Science, 2(1), 73-80.

Sabri, E. R. (2019). Consumer's purchase intention towards luxury retailer's social media advertisements - A case study of a shoe retail—UAE-Dubai Mall. Social Networking, 08(01), 39-51. https://doi.org/10.4236/sn.2019.81003

Saleem, A., \& Ellahi, A. (2017). Influence of electronic word of mouth on purchase intention of fashion products in social networking websites. Pakistan Journal of Commerce and Social Sciences (PJCSS), 11(2), 597-622.

Saunders, M., Lewis, P., \& Thornhill, A. (2016). Research methods of business students. Pearson Eductaion Ltd.

Schmidt, C. K., Miles, J. R., \& Welsh, A. C. (2011). Perceived Discrimination and Social Support: The Influences on Career Development and College Adjustment of LGBT College Students. 293-309. https://doi.org/10.1177/0894845310372615

Shashikala, R., \& Mahapatro, P. (2015). Let your research be global search-An ultimate search of. Acme Intellects International Journal of Research in Management, 10(10), 2320-2793.

Sin Wei, L., \& Tunku Abdul Rahman, U. (2014). The Attitudes of Consumers towards Viral Marketing in Malaysia.

Surjaatmadja, S., \& Purnawan, D. (2018). Store Image, Service Quality, and Familiarity on Purchase Intention of Private Label Brand In Indonesia. International Review of Management and Marketing, 8(1), 79-85..

Sv, K. K., \& Sequeira, A. H. (2014). An empirical observation of age factor's moderating role on an empirical observation of age factor's moderating role on mobile banking adoption in Rural Karnataka. International Journal of Marketing, Financial Services and Management Research, 3(9).

Taivanjargal, O., Batbayar, A., Batlkhagva, N., Tumenbayar, D., \& Enkhtaivan, U. (2018). Influencing factors on purchase intention of Smartphone users: In case of Mongolia. Invention Journal of Research Technology in Engineering \& Management (IJRTEM) Www.Ijrtem.Com, 2(6).

Tran, T. (2018). International Journal of Advanced and Applied Sciences Factors affecting the purchase and repurchase intention smart-phones of Vietnamese staff. 5(3), 107-119.

Trivedi, J. (2017). The Effect of Viral Marketing Messages on Consumer Behavior. 17(2), 84-98.

Uddin, M., Xu, H., \& Tahlil Azim, M. (2015). Factors affecting mobile handset (MH) buying decision: An empirical study. International Journal of Management and Business Research, 5(3), 225-236.

Ugonna, I. A., Okolo, V. O., Millicent, O., Sylvanus, N., \& Oranusi, I. N. (2017). Effects of Media Advertising On Consumers' Purchase Intent in Awka, Anambra State: A Study of Hero Beer. IOSR Journal of Business and Management (IOSR-JBM), 19, 50-60. https://doi.org/10.9790/487X-1904045060

Walia, N., Srite, M., \& Huddleston, W. (2016). Eyeing the web interface: the influence of price, product, and personal involvement. Electronic Commerce Research, 16(3), 297-333.

Wang, S., \& Nguyen, L. N. T. (2018). A Study on the Attitude of Customer towards Viral Video Advertising on Social Media : A Case Study in Viet Nam. The International Journal of Engineering and Science, 7(6), 54-60.

Wang, Y., Huang, Q., Davison, R. M., \& Yang, F. (2018). Effect of transactive memory systems on team performance mediated by knowledge transfer. International Journal of Information Management, 41, 65-79.

YAQOOB, Q. T. (2018). Impact of Facebook Advertisements on Purchase Intentions of Mobile Facebook Users: Investigating the Moderating Role of Brand Origin and Perceived Product Value. Tohoku University.

Yusuf, A. S., Razak, A., Hussin, C., Busalim, A. H., Yusuf, A. S., Razak, A., ... Busalim, A. H. (2018). Influence of e-WOM engagement on consumer purchase intention in social commerce. https://doi.org/10.1108/JSM-01-2017-0031

Zeithaml, V. A. (1988). Consumer Perceptions of Price, Quality, and Value: A Means-End Model and Synthesis of Evidence. Journal of Marketing, 52(3), 2-22. https://doi.org/10.1177/002224298805200302

Zia, M., Khan, M. R., \& Lashari, J. A. (2010). Effect of job rewards on job satisfaction, moderating role of age differences : An empirical evidence from Pakistan. 4(June), 1131-1139.

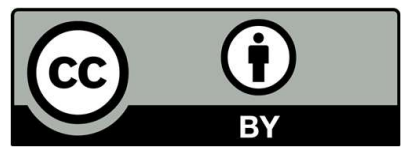

(C) 2020 by the authors; licensee Growing Science, Canada. This is an open access article distributed under the terms and conditions of the Creative Commons Attribution (CC-BY) license (http://creativecommons.org/licenses/by/4.0/). 